УДК $271.2: 279: 94(477.5-477.7)$

DOI: https://doi.org/10.33782/eminak2020.3(31).436

\title{
БЛЮЗНІРСТВО ЯК «ІСТИННА ПОБОЖНІСТЬ»: РЕЛІГІЙНІ ПРАКТИКИ СЕЛЯН-ШТУНДИСТІВ У ДРУГІЙ ПОЛОВИНІ ХІХ - НА ПОЧАТКУ ХХ СТОЛІТТЯ
}

\author{
Сергій Савченко \\ Національна металургійна академія України (Дніпро, Україна) \\ e-mail: serhijs@gmail.com \\ ORCID: https://orcid.org/0000-0002-3615-2343
}

Вивчається роль в місце блюзнірських практик к релігійному житті селянштундистів України кінця XIX - початку XX ст. Низка історіографічних стереотипів щодо історії сектантських рухів пізньоімперського періоду потребує спростування. Обгрунтовується теза, що блюзнірство, яке сприймалося як форма побожності, було визначальним для формування конфесійної ідентичності «штундарів».

Ключові слова: штундисти, штунда, ікони, іконоборство, місіонери, церква

Актуальність проблеми. В історіографії українського сектантства домінує уявлення про тотожність штунди та протестантизму на усіх етапах їх існування у Російській імперії1. Дослідників не бентежить брак доктринальної спадкоємності між усіма штундистськими сектами, викритими поліцією, місіонерами, сільськими парохами упродовж XIX ст., і баптистами 20-Х років XX ст. Імпульс, що його дістав український штундизм від контактів з німецькими баптистами, лютеранами, реформатами, назарянами й іншими протестантськими групами, є безсумнівним², але це не $є$ приводом ігнорувати проблему невідповідності між релігійністю штундистів і теологією протестантизму.

У дискусіях з православними місіонерами штундистські лідери висловлювали погляди, які не вкладалися в жоден протестантський катехізис. Зазвичай вони не мали уявлення ані про протестантську догматику, ані про «батьків» Реформації. Найчастіше вони були взагалі байдужими до теологічної тематики ${ }^{3}$. Під час полеміки або судових процесів штундисти не могли сформулювати предмет власної віри, завдаючи тим самим значного клопоту судовим експертам, а спроби накинути їм символічні тексти німецьких баптистів вони відкидали або просто не розуміли ${ }^{4}$.

Бувало так, що отримавши сигнал про «протестантів» у тій чи тій парафії, єпархіальна влада відряджала туди штатного місіонера, який готувався до полеміки за

\footnotetext{
1 Zhuk S. Russia's Lost Reformation. Peasants, Millennialism, and Radical Sects in Southern Russia and Ukraine, 1830-1917. Washington, 2004. 304 p.

2 Троицкий С. В каком отношении учение русского штундизма находится к немецкому протестантизму // Миссионерское обозрение. Санкт-Петербург, 1905. Т. 1. С. 56.

3 Боголюбов Д. Миссионерские беседы с сектантами. Харьков, 1902. 415 с.

4 Прикметно, що у 1887 р. в Катеринославському окружному суді штундисти не змогли пояснити не лише свою догматику, але й походження своїх громад. Замість них цю роботу виконали експерти, пояснивши суду «історію російського баптизму, вказавши на її початок і зв'язок з німецьким баптизмом або ново-меннонітством...». При цьому наведена експертами інформація була юридично вигідною підсудним. Див.: Распространители баптизма пред Екатеринославским окружным судом // Екатеринославские епархиальные ведомости (ЕЕВ). 1887. № 7. С. 197.
} 
спеціальною антипротестантською інструкцією. Але познайомившись зі своїми опонентами, він марно намагався підтягнути їх до очікуваних стандартів протестантизму: вони ігнорували спроби побудувати полеміку так, як їі вели католики або православні з лютеранами чи кальвіністами. Аналогічну проблему анахронічного «підтягування» світогляду штундистів до норм протестантського катехізису мали баптистські проповідники кінця XIX - початку XX ст., які будь-що прагнули розгледіти в сільських «штундарях» своїх одновірців та однодумців. Навіщо вони це робили?

В часи захоплення усім етнічним, природним, автентично-народним Гамбурзька баптистська місія відчула потребу в культурних витоках на землі тих, кого вони намагалися навернути. Бути чужинцем на батьківщині неофітів - невдала місіонерська позиція в епоху націоналізму.

Таким чином, актуальність запропонованої теми є суто академічною. Це і $є$ головною причиною того, що накопичені в релігійній царині міфи не переглядаються: вони не мають нагального суспільно-політичного виміру. Позитив цієї історіографічної ситуації в тому, що політично «неактуальна» тема має більше шансів на спокійне, зважене й об’єктивне дослідження.

Історіографічний аспект. «Звичайна схема» штундистської історії, в якій штунду без зайвої проблематизації ототожнено з протестантизмом, підтримується більшістю авторів, які так чи інакше торкалися цієї проблеми (С. Савинський, М. Кузнєцова, Т. Нікольська, А. Апанасьонок, Ю. Хитровська, Г. Коулмен, О. Безносова, С. Жук, І. Амбарцумов і багато інших $)^{5}$. Але цей концептуальний момент не акцентований, ніхто спеціально не сипле доказами на користь цієї тези. Вона виконує роль безперечного «фонового знання» і читається «між рядків» як прописна істина.

Серед західних вчених Л. Герец певно єдиний, хто окреслив інший підхід до проблеми. За його словами, зовнішня подібність російських сект (у його студії мова йшла передовсім про духоборів і молокан) та європейських протестантів, визнання тих і тих «раціоналістами» - це дослідницька пастка. Замість поважних джерельних аргументів історики використовують просту аналогію i, вважаючи питання вичерпаним, відмовляються від глибокого вивчення традиційної релігійної культури 6 .

Тож стереотипні обриси історії штунди виглядають так: селяни покидали Церкву, бо вона не вдовольняла їхні «морально-етичні запити», священики виявляли-

\footnotetext{
5 Савинский С.Н. История русско-украинского баптизма. Одесса, 1995. 128 с.; Kuznetsova Miriam R. Early Russian Evangelicals (1874-1929): Historical Background \& Hermeneutical Tendencies Based on I.V. Kargel's Written Heritage. Submitted in fulfilment of the requirements for the degree of for the degree of Doctor of Philosophy. University of Pretoria, 2009. 553 р.; Никольская Т. Русский протестантизм и государственная власть в 1905-1991 гг. Санкт-Петербург, 2009. 356 с.; Апанасенок А.В. Религиозные диссиденты в российской провинции: очерк истории духовных движений Курской губернии в конце XVIII - начале XX века. Курск, 2010. 187 с.; Хитровська Ю. Православна церква та штундизм на Правобережній Україні в другій половині XIX - на початку XX ст. // Інтелігенція і влада. 2007. Вип. 9. С. 73-84; Colemann H. Russian Baptists and spiritual revolution, 1905-1929. Indiana University Press, 2005. 304 р.; Безносова О. Евангельское движение в Российской империи (1850-1917): Екатеринославская губерния (Сборник документов и материалов). Штайнхаген: Samencorn, 320 с.; Амбарцумов И. Неправославные христианские исповедания в системе российской государственности (конец XIX века - июль 1914 г.). Дисс... канд. ист. наук. Санкт-Петербург, 2014. $256 \mathrm{c}$.

${ }^{6}$ Heretz L. Russia on the eve Modernity. Popular religion and traditional culture under the last tsars. Cambridge Un. Press, 2008. P. 78.
} 
ся «несвятими», брали гроші за виконання треб, проводили служіння і читали проповіді «незрозумілою мовою», служили царизму і панам, «грубо поводилися із селянами», тягали їх за бороди, пили горілку, гуляли з непристойними жінками і «гребували рідною для простолюду мовою»7. Селяни ж ані в догматиці, ані в богослужінні нічого не розуміли, сприймаючи виконання обрядів як данину традиції і навіть форму розваги ${ }^{8}$. Дехто додає до чинників поширення сектантства «суперечності ринкових відносин», які змушували селян ставати штундистами (ці «протиріччя» діяли якось дуже вибірково) ${ }^{9}$. Далі «хлібороби» наважувалися пожвавити свої інтелектуальні зусилля, щоб таки вдовольнити свої підвищені «релігійні потреби» і ставали «активними місіонерами протестантських учень». Ця схема поширення штунди сперта на уявлення М.Костомарова про емоційно-чутливих українців, які прагнули до «духовного, невідомого, таємничого»; на негативістські щодо Церкви висловлювання ліберальних публіцистів кінця XIX - початку XX ст.; врешті, на метафізичну тезу про «потенційну схильність (на архетиповому рівні)» українських селян «до релігійної модернізації» ${ }^{10}$.

Викладена історіографічна ілюзія породжена романтично-народницькою міфологією. Вона не витримує критики ані з конкретно-емпіричного, ані з теологічного боку. Прихильні до зручних абстрагованих узагальнень («селяни хотіли», «народ мріяв», «священики прагнули», «хлібороби боролися» і т.п.), історики забувають, що їхня наука $\epsilon$ ідіографічною. Вона, зосереджуючись на одиничному та неповторному, мусить виявляти, а не ігнорувати оригінальні способи та категорії мислення людей минулого. Немає жодної потреби вигадувати «загальні закономірності», які дивовижною та невблаганною силою змушують людей навертатися у секти. Історик не повинен занурюватися в метафізичні нетрі «колективної волі» чи «народної душі», він має вивчати мотивацію і практику сектантів-неофітів на підставі коректної та контекстуальної інтерпретації усіх доступних джерел.

Джерела. Кожен із новонавернених мав власні мотиви піти до штунди. Розповіді про духовні пошуки, автобіографічні замітки, листи-сповіді, щоденники, протоколи бесід та інші джерела оприлюднювали, як правило, випадкові обставини, які приводили людину в нову релігійну громаду («там гарно співають», «там дають гроші», «жінка привела, щоб я кинув пити горілку», «образився на батюшку», іноді - «пізнав істину», «всі пішли і я пішов» і т.д.).

Вивчаючи випадки селянських релігійних конверсій на матеріалах Катеринославської та інших єпархій, ми рідко стикалися з власне теологічною мотивацією, коли б людина усвідомила істинність учення Лютера, Кальвіна, Сімонса чи Сміта і хибність православної догматики, і прийняла рішення покинути «язичницьке капище». Якщо такі свідчення зрідка трапляються, вони є зазвичай ретроспективним обгрунтуванням розриву з Церквою, який стався давно і за інших обставин. Тим не менш, етикетка «протестанти» наклеюється на всіх, хто покинув Церкву у 60-90-ті роки XIX ст. і не увійшов до духоборницьких, хлистівських, молоканських чи старообрядницьких спільнот. Утім історики, як правило, не люблять копирсатися у теологічних

\footnotetext{
7 Присяжнюк Ю. Українське селянство Наддніпрянської України: соціоментальна історія другої половини XIX - початку XX ст. Черкаси, 2007. С. 236.

8 Присяжнюк Ю. Вказ. пр. С. 229.

9 Буланова Н. Історія християнських конфесій Катеринославщини останньої чверті XVIII - початку XX ст. Дніпропетровськ, 2007. С. 103.

10 Присяжнюк Ю. Вказ. пр. С. 239, 245.
} 
нюансах відмінностей між ними, шукаючи критерії розрізнення де завгодно, але не в релігійних уявленнях. Тому нерідко до кола «протестантів» зараховують навіть мальованців, котрі вірили, що Кіндрат Мальований є Христом, який вдруге прийшов на землю встановити Боже Царство ${ }^{11}$. Тож питання про вірування, релігійні практики й уявлення штундистів не формулюється, бо вважається вирішеним.

Терміни. Найбільш адекватною назвою для досліджуваного явища $є$ «селянські» або «народні секти». Йдеться про локальні осередки селян і мешканців невеличких міст, які мали складні стосунки з церковною владою, відмовлялися належати до місцевої парафії, хоча могли й відвідувати храм або навіть створювати неформальні групи всередині православної громади, не привертаючи уваги поліції чи пароха. Вони могли проводити власні молитовні зібрання, вступали в дебати зі священниками та місіонерами. Могли динамічно та багаторазово змінювати конфесійну належність: мальованці могли стати штундистами і навпаки, штундисти могли «пошалапутитись», молокани могли стати штундистами, а штундисти могли увійти до баптистської громади або повернутися до церковного православ'я, що нерідко й відбувалося. У сфері невловимої, розмаїтої та рухливої народної релігійності будь-які усталені класифікатори просто не діють. Тим більше, коли йдеться про примітивні та грубі класифікаційні схеми XIX ст.

Врешті, чому б не визнати оптимальним визначення штунди в енциклопедії Брокгауза й Єфрона 1903 р.: «Штундизм - секта раціоналістичного характеру, найбільш поширена на півдні Росії. Ні догматичне, ні моральне вчення секти не піддається визначенню з достатньою повнотою та ясністю; у різних окремих випадках виходять різні характеристики секти <...> Що стосується <...> терміна штундизм, то він визнається духовними письменниками тільки в умовному сенсі, оскільки самостійної секти, яку б можна було, на відміну від інших, назвати штундистською, не існує»12.

Дійсно, значна частина штундистів була, врешті-решт, асимільована євангельсько-баптистськими інституціями, але це не означає ніби їхня картина світу була тотожною друкованим баптистським віровчительним книгам. Відтак ми уникатимемо штучних термінів типу «реформація», «протестантизм», «євангельське пробудження», які ігнорують автентичні форми людської думки та поведінки, фальшують історичну дійсність на догоду апріорним класифікаціям ${ }^{13}$.

Мета статті полягає у спробі розкрити у блюзнірських практиках селянсектантів другої половини XIX - початку XX ст. той зміст, який вони самі вкладали у свої акції та висловлювання. Нас цікавить автентичний світогляд тих, кого звикли без зайвих роздумів називати «протестантами».

Ікона мала особливе значення у релігійному досвіді штундистів, а їі ритуальне спаплюження було визначальним чинником їхнього соціального життя. Нова релігійна ідентичність почала формуватися на півдні України з 60-х років XIX ст. Поступово поширюючись на весь імперський простір, вона потребувала нового символічного універсуму, який би надавав легітимності релігійному досвіду члена громади. Штундистські блюзнірські акції над православними сакраментами були зафіксовані в 70-ті роки XIX ст. Селяни, що поривали зі своїм парафіяльним жит-

\footnotetext{
11 Присяжнюк Ю. Вказ. пр. С. 239.

12 Энциклопедический словарь Брокгауза и Ефрона. Т. XXXIХа. Санкт-Петербург, 1903. С. 937.

13 Шартье Р. Парадигмы интеллектуальной истории: от коллективных представлений к авторским интенциям // Новое литературное обозрение. 2004. № 66. URL: http://magazines.russ.ru/nlo/2004/66/shart2-pr.html
} 
тям, називали Церкву «язичницьким капищем», священиків - «ідолопоклонниками», «жерцями», «книжниками та фарисеями».

Проте влада спершу намагалася закривати очі навіть на привселюдне паплюження ікон і богохульні висловлювання, хоча це кваліфікувалося як злочин ${ }^{14}$. Поліція ігнорувала звернення парохів з приводу загрози від штунди, а подеколи й сама брала участь у штундистських зібраннях і релігійних обрядах, приймаючи «євангельську віру»15. Міністр внутрішніх справ відмовився засилати відомих чаплинських сектантів у «віддалені губернії», а коли обурені священники зажадали пояснень, він порадив їм протиставити єресі не допомогу урядників і суддів, а «пастирську опіку духовних осіб про підлеглу їм паству...»16.

У 1880-ті роки антицерковні акції та висловлювання штундистів радикалізуються, а їхня ненависть до ікон вражала своєю патологічністю. На співбесідах єпархіальних місіонерів з провідниками сектантів питання про ікони майже завжди ставилося на перше місце. Деякі сектанти погоджувалися на розмови з місіонерами лише за умови, що йтиметься про ікони ${ }^{17}$. «Було наперед відомо, - згадував о. Дмитро Боголюбов - що штунди бажають вести бесіду зі мною про шанування ікон. Я радів, що мова йтиме саме про цей предмет, який служив справжнім каменем спотикання»18. У цій тематиці штундистські теологи вважали себе найбільш обізнаними та компетентними. Їм здавалося, що аргументи на їхню користь лежать на «на рядках» біблійних сторінок. Бесіди про ікони завжди збирали масу народу, що, загалом, спростовує стереотипи про виняткове обрядовірство селян та їхню нехіть до інтелектуально-теологічного аспекту релігії19.

3 точки зору селян-штундистів, їхнє блюзнірство було істинною євангельською побожністю. Боротьба з іконами й іншими сакраментами формувала нову ідентичність в умовах номінального домінування православ'я. Фобія щодо ікони послідовно навіювалася усім членам штундистської громади, починаючи з етапу неофітства. Жоден інший предмет православного культу не викликав стільки люті та ненависті, одна лише згадка про ікону могла спровокувати агресивну реакцію, бійку і непохитне бажання «страждати за віру» 20.

Деякі сектанти могли піддатися умовлянням місіонерів й осінити себе хресним знаменням, але за умови, що поруч не буде «дерев'яного бога»21. «Дехто із селян, писав у звіті єлисаветградський чиновник, - що належали до секти штундистів, не визнаючи ікон, виносили їх з хати і клали у коморі. Інші глумилися над ними, а де-

\footnotetext{
14 Свод законов Российской империи. Т. 15. Уложение о наказаниях. Санкт-Петербург, 1912. С. 23-27. 15 Краткое жизнеописание баптиста Егора Никаноровича Иванова // Материалы к истории и изучению русского сектантства и раскола под редакцией Владимира Бонч-Бруевича. Вып. 1. СанктПетербург, 1908. С. 32-40; О штундистах-баптистах в с. Шолохове и ближайших к нему селениях Екатеринославского уезда // Екатеринославские епархиальные ведомости. 1886. № 11 . С. 288303.

16 Лебединцев П., прот. Баптизм или штунда в Киевской губернии // Киевская старина. 1885 . № 3. С. 491-518.

17 Из жизни миссии Екатеринославской епархии. Миссионерские курсы в с. Гришино Бахмутского уезда // ЕЕВ. 1912. № 6. С. 259.

18 Боголюбов Д.И. Миссионерские беседы с сектантами. Харьков, 1902. С. 325.

19 Первая моя беседа со штундистами и хитрые приемы вожаков этой секты (из записок миссионера) // Миссионерское обозрение. Киев, 1896. Кн. 1, март. С. 33.

20 Вероучение сектантов Екатеринославской епархии и его опровержение // ЕЕВ. 1889. № 15. С. 429. 21 Ibid.
} 
які зачиняли ними вікна, використовуючи замість віконниць»22. «Штундист Євфимій 3-ченко, бажаючи завадити своїй православній дружині молитися, свистів і лаявся, щойно вона починала молитися, і він же, лаючись, кинув хрест на підлогу і почав топтати його» 23 . В періодиці описувалися випадки, коли штундисти прив'язували хрест до конячого хвоста і тягали по землі в присутності православних ${ }^{24}$. Подібними були іконоборницькі акції інших сект, яких ніхто не підозрював у протестантизмі. «Немоляки ставилися до хреста та ікон вкрай блюзнірськи. Нерідко можна було чути, що немоляки порубали ікони і зробили з них лавки, або облаяли їх поганими словами, або плювали на них» 25 . «Духовні християни» із завзяттям бралися за виколювання чи вирізання очей на іконах, виготовлення з них городніх опудал 26.

Акції з паплюження ікон проводилися у вигляді публічної вистави, що була розрахована не лише на своїх, але й православних сусідів і представників місцевої влади. Типологічна подібність і масовість таких випадків навіює думку, що, можливо, ці акції були усвідомленим викликом чинному праву Російської імперії, зокрема, тим статтям «Уложения о наказаниях», які передбачали кримінальне покарання за публічно скоєне блюзнірство 27 . Подібні факти дозволяють говорити про актуалізацію архаїчного культу висміювання та «осоромлення божества», своєрідного ритуального сміху28. Ритуальне переміщення ікони з «красного кута» на город кардинально змінювало знакову ситуацію: святиня, яка лише нещодавно була об'єктом пошани та молитовних сподівань, перетворюється на засіб для відлякування птахів і місце для сидіння. Знищувалася головна функція священного образу - символічно співвідноситися з Першообразом.

С. Троїцький, один з перших богословів, який провів докладний теологічний аналіз штунди, зауважив, що «аргументація штундистів із Святого Писання, порівняно з протестантською, дуже незначна, а доказів з творів Отців та вчителів Церкви, якими зміцнюють своє учення протестанти, штундисти не мають зовсім»29. Дійсно, у штундистській риториці був непомітний протестантський пафос розвінчування народних марновірств. Мотивація іконоборства супроводжувалася цитуванням старозавітних текстів, але без контексту й елементарної герменевтики. «Ось як язичники служили своїм богам, так ви - іконам. Різниці ніякої немає. Тому ми вважаємо, що послання Єремії викриває вас за язичницькі звичаї...»30. Місіонери теж не занурювалися в іконологічне богослов'я: вони обмежувалися контрцитатами, апелювали до формальної логіки та здорового глузду, вказували на використання юдеями священних зображень херувимів і серафимів, пригадували як Хрис-

\footnotetext{
22 Чернышев В.М. Меч обоюдоострый. Конспект по сектоведению. Киев, 2000. С. 26.

23 Айвазов И. Состояние сектантства и раскола и деятельность православной миссии в Екатеринославской епархии за 1903 г. // ЕЕВ. 1904. № 7. С. 216, 220-221.

24 Сектантство и его пропаганда в Сибири // Миссионерское обозрение. 1911. № 1. С. 338.

25 Вероучение немоляков Нижегородской губернии // Миссионерское обозрение. 1902, январь. C. 1049-1053.

26 Zhuk S. Op. cit. P. 212.

27 О преступлениях против веры, и о нарушениях ограждающих оную постановлений // Уложение о наказаниях уголовных и исправительных и Устав о наказаниях мировыми судьями налагаемых. Москва, 1872. С. 43.

28 Бахтин М. Творчество Франсуа Рабле и народная культура средневековья и Ренессанса. Москва, 1990.543 c.

29 Троицкий С. Вказ. пр. С. 61-62.

30 Боголюбов Д. Вказ. пр. С. 334.
} 
тос використав для роз'яснення своєї думки зображення кесаря на динарії, застосовували аргумент про «Біблію для неграмотних» або апелювали до психологічної доцільності вшановувати сакральні образи і предмети ${ }^{31 . ~ « І к о н а, ~ в і д в о л і к а ю ч и ~ н а-~}$ шу увагу від зовнішнього, тілесного, допомагає нам утримувати наші думки і почуття у напрямку до Бога»32. Православні місіонери були змушені обгрунтовувати догматично сумнівні практики, наприклад, антропоморфну іконографію БогаОтця, що була суворо заборонена VII Вселенським Собором і Стоглавим Собором у Москві $^{33}$. В цілому, Церква приділяла мало уваги христологічному обгрунтуванню ікони, покладаючись на авторитет старовини. Навіть о. Дмитрій Боголюбов, під час дебатів зі штундистами, рідко акцентував на зв'язку між христологією та культом ікон ${ }^{34}$. Вважалося, що «примітивні» й «алогічні» селяни просто нездатні збагнути інтелектуально складні аргументи.

Блюзнірські ритуали штундистів були формою антиповедінки у рамках архаїчної релігійності, що виявляла себе в практиці магічної «зворотності» 35 . Так, на Страсну п’ятницю під час хресного ходу з плащаницею штундисти виходили на вулицю і показово їли м'ясо у присутності шокованих православних парафіян ${ }^{36}$. Хресне знамення трактувалося як «печатка антихриста, яку він наклав на праву руку і чоло людям»37.

Радикалізм блюзнірських акцій залежав від міри сакралізації тих чи інших символів у народній побожності. Дмитрій Боголюбов марно намагався переконати штундистів, що Церква шанує ікони, але не вірить в те, що це «боги»: «Ікони православні - не боги, лише зображення фарбами істинного Бога і святих Його. Іконам ніхто не служить як живим богам. Ікона сама по собі не може когось вбити чи помилувати»38. Факти надмірної сакралізації ікон серед православних парафіян він пояснював потребою логічного згортання фраз: «Коли прості люди називають ікону богом, то тільки в переносному значенні... Увійдіть до волосного правління. На стіні ви побачите царський портрет, а під ним підпис: «Імператор Микола II». Тож спитаю вас: хіба живий цар висить на стіні?»39. Утім цей аргумент «від здорового глузду» не справляв належного враження на тих, хто сам ще вчора обожнював ікони і називав їх «богами». У масовому сприйнятті не лише зображений святий, але й сама ікона була суб'єктом чудотворення ${ }^{40}$. Йдеться про «архаїчну концепцію ототожнення Бога з матерією»41. Карло Гінзбург назвав це явище «народним матеріалізмом», коли матерію наділено божественними атрибутами ${ }^{42}$. У чомусь мож-

\footnotetext{
31 Протоколы миссионерских комитетов // ЕЕВ. 1888. № 6. С. 91-99.

32 Протоколы миссионерских комитетов // ЕЕВ. 1888. № 1. С. 7.

33 Протоколы миссионерских комитетов // ЕЕВ. 1888. № 6. С. 91-99.

34 Христологічний аргумент в його «Миссионерских беседах», який дещо нагадував теологію преп. Іоанна Дамаскина, зустрічаємо лише один раз. Див.: Боголюбов Д. Вказ. пр. С. 344.

35 Лотман Ю.М. Роль дуальных моделей в динамике русской культуры (до конца XVIII в.) // Лотман Ю.М. История и типология русской культуры. Санкт-Петербург, 2002. С. 88-115.

36 Писклявский М. Замыслы сектантов. Журнал «Христианин». 1911, январь. Редактор И. Проханов // ЕЕВ. 1911. № 9. С. 264.

37 Назаревский Н. О кресте и крестном знамении // ЕЕВ. 1911. № 1. С. 26-27.

38 Боголюбов Д. Вказ. праця. С. 334.

39 Ibid. C. 377.

40 Романова О. Очікування «чуда» як основа народної побожності (Київська митрополія, XVIII ст.)

// Український історичний журнал. 2010. № 1. С. 84-106.

41 Элиаде М. Трактат по истории религий. Т. 2. Санкт-Петербург, 1999. С. 29.

42 Гинзбург К. Сыр и черви. Москва, 2000. С. 152.
} 
на побачити аналогію з віруваннями первісної людини в засадничу тотожність зображень та оригіналів, хоча «примітивність» народної релігійності XIX ст. не варто перебільшувати ${ }^{43}$.

На відміну від протестантів, які бачили в іконах «Біблію для неграмотних», декорації або просто народні марновірства, штунда приймає православну концепцію «енергійності ікони», але з протилежним знаком. Деякі штундисти були переконані, що ікона не є образом Бога, натомість - вона відображає темні сили, навіть дотик до неї здатен осквернити людину44. По відношенню до неї доречною є лише «антиповедінка». Коли неофіт не міг відкрито знищити ікону, побоюючись поліції та суду, він міг тримати їі в хаті, але під час молитви перед нею використовував нецензурну лайку 45 або повертався до неї спиною46. «Не слід поклонятися іконам тому, - вважали ростовські сектанти, - що Божа святість може вселятися тільки в людину, до предметів бездушних причетна бути не може» ${ }^{47}$. Феоктист Дунаєнко у полеміці з місіонером В. Скворцовим заперечував шанування ікон на тій підставі, що «нерухомі речі не можуть бути святими» ${ }^{48}$. Селянин Юхим з місіонерською метою топтав хрест ногами, намагаючись переконати членів своєї сім'ї, що це всього лише «шматок дерева» ${ }^{49}$. Вже згадані штундисти села Моринці відмовлялися цілувати хрест, оскільки врешті усвідомили, що «хрест дерев'яний - не божество»50. Сектанти вважали, що церква шанує ікони, оскільки вірить, ніби в них «вселяється Божа святість», подібно до того, як язичники вірили в одухотвореність своїх ідолів.

Предметом нищівної деконструкції у блюзнірських акціях було те, що Р. Отто назвав «нумінозністю» - внутрішньою серцевиною релігії51. Богохульство та наруга над святинею, як стверджує О.Смілянська, були однорідними явищами ${ }^{52}$. Але 3 точки зору штундистів, «Бог православних» був «іншим Богом», не тим, в кого вірували «істинні християни», тож святині православних - це лжесвятині. Саме тому, що паплюжилася «чужа» релігія, штундистам здавалося, що їхні акції діставали божественну санкцію. Чинити опір «хибній» сакральності, наражаючись на ризик покарання, означало здійснювати подвиг аскези та побожності, це був шанс стати «мучеником за віру».

Ставлення до ікон переносилося і на святих. При цьому штундисти особливо запекло ненавиділи найпопулярніших з них. «Зі святих угодників Божих, - писав I. Троїцький, - злість і ненависть сектантів найбільше вихлюпується на святителя і чудотворця Миколая, цьому святому штундисти приділяють скільки уваги, наче

\footnotetext{
43 Леви-Брюль Л. Сверхъестественное в первобытном мышлении. Москва, 1937. С. 8.

44 Вероучение сектантов Екатеринославской епархии и его опровержение (по протоколам Миссионерских комитетов и другим официальным документам) // ЕЕВ. 1889. № 13. С. 363-364.

45 Лебединцев П. Указ. раб. С. 494.

46 Писклявский М. Замыслы сектантов. Журнал «Христианин». 1911, январь. Редактор И. Проханов // ЕЕВ. 1911. № 9. С. 264.

47 Белый Митрофан, свящ. Сектантство на хуторе Узеки Ростовского-на-Дону округа // ЕЕВ. 1904. № 19. С. 629.

48 Дунаенко Ф. До конца претерпевший. URL: http://www.rusbaptist.stunda.org/dunaenko.htm

49 Айвазов И. Состояние сектантства и раскола и деятельность православной миссии в Екатеринославской епархии за 1903 г. // ЕЕВ. 1904. № 7. С. 220-221.

50 Березницкий И. Двадцатилетняя борьба с приходскою штундою и троекратное одоление // Миссионерское обозрение. 1896, июль-август. С. 50.

51 Отто Р. Священное. Санкт-Петербург, 2008. С. 12.

52 Смилянская Е. Волшебники. Богохульники. Еретики. Народная религиозность и «духовные преступления» в России XVIII в. Москва, 2003. С. 218.
} 
від нього все в Церкві пішло не за законом. Ім'я його так само ненависне для штундистів, як для розкольників ім'я патріарха Нікона»53. А о. Іоанн Наумович в селі Моринці зустрів серед штундистів прибічників Арія, що симпатизували єресіарху тільки за те, що той одержав ляпас від ненависного св. Миколая54. Не менше ненависті викликала Діва Марія. Факти образливих висловлювань на її адресу повсякчас фіксувалися місіонерами 55 .

Задля виправдання блюзнірського вчинку новонавернений мав витворити своєю уявою спотворений образ Церкви, перебільшуючи гріховність свого парафіяльного життя. Критика Церкви диктувалася не богословськими міркуваннями, а необхідністю підтримувати «праведну», «істинну» ідентичність на противагу «старій». «Коли ми були православними..., ми були не християни, а скоріше язичники, тому що палили тютюн, пили горілку, грали в козла і блудили, а тепер ми відкинули будь-яку підлість, лицемірство, заздрість і лихослів'я»56.

Один із способів викликати огиду до Церкви - ототожнити їі служителів з відразливими персонажами біблійної історії. Рябошапка вчив своїх послідовників, що «православний священик - це жрець і ненависний брехун, який належить до числа тих самих архієреїв і священиків, які розіп'яли Христа, і яких викривав Господь». Священики - «дармоїди, ледацюги, жадібні, пройдисвіти, лжепророки. Рід свій вони ведуть від царя Ірода... Жезл архієрейський - ключ від пекла»57. Ікона - символ всього цього «гріховного минулого», найбільше шанований «грішниками». Тож поквитатися з нею - священний обов'язок істинного християнина.

Ікона була частиною парафіяльної повсякденності, яка «є найвищою реальністю людського досвіду в тому сенсі, що вона є особливим світом, в який ми вкорінені найміцніше, бо не піддаємо сумніву»58. Інтерпретація блюзнірства як «ритуалу переходу» від профанного (старого церковного життя) до сакрального (нової громади обраних) $є$ вельми доречною: спаплюження ікони сприймалося як відречення від гріха, після чого неофітові дозволялося стати «духовним християнином»59. Привселюдна наруга над церковними сакраментами була ініціацією, символізуючи соціальну смерть «вітхої», «природної», «профанної» людини та народження нової «священної» особистості 60. Селянин Бойко згадував, як перед прийняттям у баптисти, пресвітер зняв з нього хрест та кинув у «відхоже місце» під тим приводом, що православні - «люди темні і не знають Писання, а в Писанні заборонено поклонятися хресту»61. У такий спосіб спалювалися усі емоційні зв'язки зі «старою» Церквою. Між нею й адептом секти поставало психологічне провалля, що унеможливлювало повернення. Після акту наруги «грішник» зникав, натомість «духовно народжувалася» нова людина - «істинний християнин», що бачив світ зовсім по-

\footnotetext{
53 Троицкий С. Вказ. пр. С. 60.

54 Из писем прот. Иоанна Наумовича о противоштундовом миссионерстве (из частной переписки) // Миссионерское обозрение. Киев, 1896. Кн. 1., июль-август. С. 44.

55 Троицкий С. Вказ. пр. С. 60.

56 Дементьев И. Из дневника екатеринославского епархиального миссионера // ЕЕВ. 1889. № 6. C. 186.

57 Троицкий С. Вказ. пр. С. 67.

58 Гирц К. Интерпретация культур. Москва, 2004. С. 137.

59 Геннеп А., ван. Обряды перехода. Систематическое изучение обрядов. Москва, 1999. С. 8.

60 Еліаде М. Мефістофель і андрогін. Киев, 2001. С. 99.

61 Открытое письмо крестьянина Бойко к православным христианам о том, как он совратился в баптизм и попал потом ложь этого учения // EЕВ. 1912. № 6. С. 263.
} 
іншому. Те, що профанам здавалося блюзнірством, в соціумі «нових християн» ставало «істинною побожністю».

Подібна психологія та практика була властива усім неофітам сектантства незалежно від конфесійної ідентичності. «В зібранні хлистів новонавернений приносить дві ікони - Спасителя та Божої Матері (переважно ті, що дарувалися йому покійними батьками для благословення), кидає їх серед кімнати на землю i, ставши на них ногами <...> - промовляє клятву вірності хлистівству; затим він кладе їх у порожню діжку <...>, знімає з себе спідню білизну і відкрито, привселюдно, осквернює їх найогиднішим чином»62. «Мене прийняли із задоволенням, - згадував колишній шалапут Павло Кулібка, - і так змогли вплинути на мене, що, коли почали хулити обряди Православної Церкви і лаяти її служителів, мене це анітрохи не бентежило... Вони переконали мене ставитися до священиків з ненавистю». Лише згодом, відійшовши від шалапутської громади, Кулібка почав відчувати муки сумління, сумніви, каяття та дуже сильну ностальгію. «Бувало, коли бачив священика, церкву, ікони, мимоволі лилися сльози з очей»63. Такі свідчення можна було б списати на вигадки небезсторонніх осіб, якби не масовість джерел, які фіксують такі дані.

У сектантській ініціації важив момент публічності, героїка блюзнірського акту, тому про всі випадки нищення та паплюження ікон дізнавалася місцева влада. Богохульник добре знав, чим ризикував. Відповідно до «Уложения о наказаниях», за свій вчинок він мав провести на каторзі тривалий період свого життя. Ікони й інші церковні атрибути зазвичай осквернялися у присутності членів громади, що засвідчувало серйозні наміри новонаверненого. Селянин Київської губернії Терентій Книжник показово порубав і спалив у печі свої ікони 64 . Герасим Балабан на знак розриву з православ'ям розбив ікону святого Миколая перед мешканцями села, супроводжуючи цю акцію дошкульними словами на адресу святого 65 . Він намагався продемонструвати присутнім слабкість «православного Бога» і засвідчити, що «ікона за себе заступитися не може»66.

У блюзнірських акціях можна побачити і такий аспект як «випробування Бога», зазвичай його виконували в період неофітства для того, щоб переконати себе у правильності вибору: «Візьми ікону, кинь ії у багнюку, а потім скажи: підіймися. Якщо вона Бог, то підніметься і сама очиститься від бруду», - вчив баптист Сидоренко своїх односельців ${ }^{67}$. Іноді штундисти доводили, що ікона - не Бог, к такий спосіб: клали на неї монету і заявляли присутнім православним: «Просіть гроші, якщо він живий Бог, то дасть їх вам»68. У відповідь на місіонерські напучування можна було почути: «Нехай ваші ікони доведуть свою святість, я баба - спалила свою ікону, а вона вогонь не згасила і мене не покарала»69. Розкольник, що перей-

\footnotetext{
62 Буткевич Т. Указ.соч. С. 55.

63 Краснокутский О. 0 шалопутстве // ЕЕВ. 1889. № 4. С. 89, 90.

${ }^{64}$ Центральний державний історичний архів України у м. Києві. Ф. 127. Оп. 690. Спр. 1364 «Дело Терентия Афанасьевича Книжника. 1889 г.». 4 л.

65 Лебединцев П. Указ. соч. С. 498.

66 Вероучение немоляков Нижегородской губернии // Миссионерское обозрение. 1902, январь. C. $1049-1053$.

67 Вред для религиозной и общественной жизни, причиняемый Волосскими баптистами, осужденными Екатеринославским окружным судом 22 мая 1889 г. // ЕЕВ. 1889. № 20. С. 592.

68 Дементьев И. Из дневника екатеринославского епархиального миссионера. Александровск, январь 1-3 // ЕЕВ. 1889. № 8. С. 212.

${ }^{69}$ Скворцов В.М. Курское иконоборческое злодеяние и чудесное знамение во свидетельство истинности и святости православной веры // Миссионерское обозрение. 1898, апрель. С. 536.
} 
шов у штунду, пояснював це тим, що святий Миколай не покарав його за виколювання очей на іконі: «Якщо це Бог, то він за образу мене покарає»70.

Штундистське блюзнірство не можна поверхово трактувати як «протестантську» критику окремих елементів православної побожності, що не грунтувалися на «Писанні»71. Релігійні уявлення більшості штундистів мали небагато спільного 3 протестантською догматикою. Місіонери у 1886 р. відвідали Комісарівку Верхньодніпровського повіту Катеринославської губернії, де мали намір провести диспут 3 «протестантами». Як виявилося, причиною їхнього відпадіння від Церкви було бажання «розуміти те, що читалося і співалося в храмі і проводити свята похристиянськи, тобто без пияцтва і сварок...». Вони щиро вважали, що сварки і пияцтво - частина православного стилю життя. Разом з тим, звітувалися місіонери, «сектанти висловилися, що вони Бога визнають, але троїчність розуміють своєрідно, а саме: Сина Божого визнають не окремою іпостассю, а лише словом, тобто звуком, який виходить з вуст Отця... Христа вважають звичайною людиною. Він одержав Духа Святого при хрещенні від Іоанна, як і будь-який віруючий...»72.

Природно, що православні оцінювали штундистські акції як прояв демонічного. Наруга над сакральними предметами - типова реакція бісів, що сидять у людині, на благодатну енергію священних символів. У багатьох випадках поведінка штундистів збігалася з нормативною поведінкою тих, кого вважали «біснуватим»73. Під час вимушеної участі в громадських ритуалах (освячення криниці, поля, похорон та ін.), вони ухилялися від цілування хреста, а під час окроплення свяченою водою намагалися сховатися74. За спогадами Дунаєнка, він був свідком вінчання, «про яке заговорили в багатьох селах. Наречений був православним, а наречена - штундисткою. Після вінчання священик благословив їх і дав поцілувати хрест. Наречений поцілував, а наречена відштовхнула розп'яття. Народ почав обурюватися: «Дивіться, що вона зробила», - говорили вони, - “Бога штовхнула!”»75. Через подібні випадки слово «штунда» стало прозивним, а про штундистів ширилися чутки в дусі гоголівської демонології. Наприклад, у Херсонській єпархії знаходилися свідки того, що сектанти «моляться лише вночі і не інакше, як ставши довкола діжки з водою; тоді їхній бог виринає з води і вчить їх нової віри»76. Були й такі «очевидці», що запевняли, ніби штундисти поклоняються величезній жабі: вона вистрибувала з бочки та проповідувала. Хтось вважав, що штундисти на своїх зібраннях моляться не Богові, а Іроду 77.

Для православних селян ще однією підставою підозрювати зв'язок штундистів з нечистою силою було те, що, на відміну від хуліганського блюзнірства, штундистські акції рідко діставали очевидну для всіх небесну кару: у вигляді раптової

70 Шалкинский С. Отчет о состоянии раскола Екатеринославской епархии в 1907 г. // ЕЕВ. 1908. № 8. С. 166.

71 Як зауважив о. Сергій Булгаков, «картини релігійного змісту, що зображують євангельські події, не зустрічають для себе принципового заперечення в протестантському світі». Див.: Булгаков С. Православие. Очерки учения православной Церкви. Киев, 1991. С. 170.

72 К истории комиссаровских штундистов в Верхнеднепровском уезде Екатеринославской губернии // ЕЕВ. 1886. № 3. С. 71.

73 Мельникова Е. Отчитывание бесноватых: практики и дискурсы // Антропологический форум. Санкт-Петербург, 2006. № 4. С. 220-263.

74 Березницкий И. Двадцатилетняя борьба с приходскою штундою... С. 51.

75 Дунаенко Ф. Указ. соч.

76 Березницкий И. Указ. соч. С. 49.

77 Рационализм на Юге России // Отечественные записки. Санкт-Петербург, 1878. № 3. С. 206-207. 
смерті, паралічу рук чи ніг, нещасного випадку тощо. При цьому і ритуальне блюзнірство, і хуліганське могли бути тотожними за формою і технікою виконання, зокрема, могли прибирати вигляду сміхової пародії на православний обряд. Ось типова історія про хуліганську витівку, яка служила ілюстрацією для пастирських напучувань. «Сергій Максимов <...> часто в нетверезому вигляді дозволяв собі непростимі жарти, знущання та висміювання святих осіб і речей. Вдягнувшись у брудну рогожу він, як наче у ризах, підходив до святих ікон і читав Євангеліє й Апостол, змішуючи святі слова з непристойною лайкою. Брав до рук посудину з водою і віник - ходив, вимовляючи замість звичайних слів, що належали священику, знову таки огидні та мерзенні слова...»78. Parodia sacra скінчилася паралічем і смертю кощунника, але для штундистів такі речі оберталися лише бійкою з православними парафіянами, арештом, судом, виселенням за межі сільської громади або засланням. У цьому не було жодної містики.

Якоюсь мірою паплюження ікони можна пояснити розчаруванням в її чудотворних можливостях: штундисти могли відтворювати архаїчну, відому ще з давньоруських часів, практику «покарання божества» за невиконання волі їі власника79. Так, В.Розанов писав про випадок, коли селяни намагалися продати ікону св. Миколая за те, що той не виконав їхніх молитовних прохань. «А то який же він бог, коли обдурив!»80. Враховуючи споживацький характер селянської релігійності, така інтерпретація видається припустимою, але тут йдеться радше про випадки блюзнірства серед православних парафіян, які теж часто реєструвалися церковною владою.

Селянське іконоборство мало ще один аспект, без з'ясування якого картина буде неповною. Мова йде про свідому провокацію, що ставила за мету спричинити гоніння з боку влади задля здобуття мученицьких вінців. Безумовно, «істинні християни», якими відчували себе штундисти, мають зазнавати гонінь від «книжників», «фарисеїв», «первосвящеників», «язичників» і «римських стражників». Провокування таких гонінь за допомогою паплюження ікон, хреста, євхаристії ніби відтворювало первинну сакральну ситуацію, ритуально повертало штундистів «у ті часи», коли все починалося 81 . «Баптистів почали переслідувати, забороняти зібрання, саджати до в'язниць... Беззахисні і смиренні, вони терпляче витримували все і лише в молитвах своїх зверталися до Господа», - $з$ мартирологічним пафосом писав журнал «Баптист» у 1911 р., ототожнюючи баптизм початку XX ст. з селянською штундою 60-90-х років XIX ст. і, таким чином, створюючи для баптистського руху мученицьку біографію 82 . «Хочу описати вам, що в нас 8 червня цього року відвідав Господь своїм випробуванням деяких братів і сестер сильними тортурами від людей, що не знають Господа, - писав «брат Н-ко из Таганрога»83. «8-го числа в суботу до будинку власника крамниці зібрався натовп до 200 чоловік, схопили В. Двойникова та кажуть: «Ну, якому Богові поклоняєшся?», били його жорстоко,

\footnotetext{
78 Наказанное кощунство // Новгородские епархиальные ведомости. 1897. № 22. С. 1429.

79 Успенский Б.А. Филологические разыскания в области славянских древностей. Москва, 1982. C. 114.

80 Розанов В.В. Около церковных стен. Москва, 1995. С. 154.

81 Така практика цілком вписується в універсальні структури міфологічного мислення, досліджені Мірча Еліаде: Див.: Аспекты мифа. Москва, 2010. 251 с.

82 Тимошенко М. Баптисты и их противники // Баптист. 1911. №9. С. 67.

83 Братский листок. 1907. № 1. С. 6.
} 
майже до смерті...»84.

Селянин Дмитро Шепетков, шукаючи можливості невинно постраждати, свідомо спровокував свого знайомого православного побити його «за віру Христову» 85 . Діставши вінець «мученика», Шепетков у такий спосіб символічно скріпив своє навернення до «істинної віри». Революціонер-народник С. Степняк-Кравчинський у романі про штундиста Павла Руденка яскраво передає атмосферу семантичних асоціацій штундистів з апостолами та мучениками: «Брати зібралися на урочисте i печальне моління, щоб вшанувати пам'ять свого першого учителя і мученика. Зібралися всі, старі і малі... Гонителі-юдеї - це були церковники; фарисеї та книжники - попи та чиновники, які, не маючи сили здолати їхнього вчителя словом, схопили його і вбили у в'язниці... Це не Стефан - це про їхнього Лук'яна пише апостол» 86.

«Громада обраних», подолавши незворотний плин історії, опинилася в центрі подій, що вирішували долю Всесвіту. Через подібні розповіді, що ширилися друком і усно, розрізнені локальні осередки селян-богошукачів перетворювалися на нову «уявлену спільноту», що діставала легітимність (у власних очах) через повторення/відтворення сакральних архетипів. Мартирологічні тексти забезпечували концептуальну осмисленість і самототожність «істинних християн» перед лицем гонителів. Історія Нового Завіту повторювалася знову і знову, занурюючи «обраних» у міфічну позачасову реальність «вічного повернення». Власне, такою була парадигма усіх форм і різновидів народного сектантства. Хлисти та шалапути мали власних живих «христів» і «богородиць», штундисти - живих «апостолів» і «мучеників».

Висновки. В акціях і деклараціях сектантів були відсутні реформаторські ідеї, натомість ми бачимо пафос космічного оновлення. Церкву, на думку штундистів, потрібно не вдосконалювати, а знищити з лиця землі, бо в новому щасливому світі штунда замінить усі релігії. Недаремно серед них ходили чутки про «таємний штундизм» царя, який незабаром розпочне гоніння на православних, а штунду зробить «панівною релігією»87. Я. Бондарь у 1900 г. знищив усі свої ікони, але лишив на стіні портрет Миколи II. Він пояснював це тим, що імператор насправді був штундистом, хоч і мусив це приховувати 88 . Схожими ідеями керувалися і шалапути. Навіть в «інтелігентському» сектантстві існували подібні мрії. І. Проханов, вважаючи себе пророком, твердив, що прийдуть часи, коли «євангельські християни проповідуватимуть у православних храмах». Звісно, після вигнання звідти «духовно мертвих» попів і парафіян. Він розглядав Росію як «язичницьку невіруючу країну», а себе як пророка «живого Христа»89.

Штунда - це малоструктурований, теологічно розмитий соціум, мережа авто-

\footnotetext{
84 Братский листок. 1907. № 1. С. 6.

85 От кр. Абрамова из Нижегородской губ. Материалы из архива Я. Духонченко. История евангельских христиан-баптистов - (Евангельское движение в Евразии. Материалы и документы. ЕААА, 2004) - (CD-ROM).

86 Степняк-Кравчинский С. Штундист Павел Руденко. URL: http://www.rusbaptist.stunda.org/shtundist.htm 87 Сектантство и его пропаганда в Сибири // Миссионерское обозрение. Санкт-Петербург, 1911. № 1. С. 338.

88 Опря І. Утиски адептів пізньопротестантських конфесій у Правобережній Україні наприкінці XIX - на початку XX ст. // Український історичний журнал. 2011. № 2. С. 47.

89 Пузынин А. Традиция евангельских христиан. Изучение самоидентификации и богословия от момента ее зарождения до наших дней. Москва, 2010. С. 259.
} 
номних або зовсім не пов'язаних між собою релігійних груп (здебільшого селянських або генетично пов'язаних із селом). Їхній «протестантизм» - не особливість віроучення і не самоідентифікація, а асоціативні враження журналістів, публіцистів, чиновників, місіонерів, богословів, які на підставі окремих прикмет (наприклад, читання Біблії та відмови від іконошанування) класифікували їх як «протестантів», заповнюючи в такий спосіб прогалину у власній картині світу. Тривалий час ці групи перебували за межами євангельско-баптистського руху, організованого Гамбурзькою місією у другій половині XIX ст., а іноді й протиставляли себе «обрядовим баптистам», сповідуючи вільне духовне життя і «духовні» трактування Св. Писання. Навіть ті групи, які врешті увійшли до баптистського союзу, зберігали свою світоглядну своєрідність, не ототожнюючи свою віру із віровчительними катехізисами.

Так чи інакше, розкидані по всій імперії штундистські групи, незалежно від того як вони самі себе називали («духовні християни», «просто християни», «євангельські християни» і т.п.) намагалися сконструювати свою ідентичність шляхом протиставлення себе релігійній більшості. За допомогою ритуального спаплюження символів православ'я адепти «нової віри» створювали нову дихотомічну дійсність, де був лише чорний і білий колір. Релігійний акт блюзнірства мав захистити новий релігійний вибір, нову віру та їі адептів від асиміляції більшістю; він виконував роль ініціації, що мусила відділити «пшеницю від полови», відірвати людину від їі минулого, оцінити ії придатність для виконання «великої місії»; нарешті, йдеться про жертовний подвиг, який заміняв православну аскетику. Блюзнірством і його привселюдною маніфестацією провокувалися гоніння на «істинних праведників» 3 боку «книжників і фарисеїв» (світської та церковної влади). Міфологічний тип релігійності штундистів передбачав постійне відтворення чи повторення біблійних парадигм, бо у міфові ми знаходимо те, що «можна назвати вічним»90.

17 квітня 1905 р. імператор Микола II своїм Указом «Про зміцнення засад віротерпимості» оголосив свободу віросповідання і дискриміновані сектанти набули легального статусу. Перехід з православ'я в інші християнські об'єднання вже не оцінювався як кримінальний злочин ${ }^{91}$. Утім легальний статус зобов'язував учорашніх штундистів виглядати пристойно в очах влади та суспільства, що спонукало до відмови від низки ритуальних практик.

У баптизмі та євангельському християнстві, куди влилася більша частина локальних штундистських громад, ставлення до шанування ікон було критичним, але блюзнірська риторика та практика втратила колишню полемічну гостроту. Micioнери зафіксували цю тенденцію: «Багато хто з баптистів почав інакше ставитися до святих зображень. Одні й надалі вважають їх ідолами та кумирами, інші ж визнають їх істинними зображеннями, доводять лише, що не можна поклонятися перед іконами»92. Загалом, це відбувалося в руслі нормалізації нової віри: у штундистів, які критикували плату за треби, з'являються натуральні повинності на користь пасторів (наприклад, «Божа курка»); замість утримання священника та його родини, що так обурювало селян, доводилося сплачували десятину на утримання

\footnotetext{
90 Мелетинский Е.М. От мифа к литературе. Москва, 2001. С. 11.

91 Полное собрание законов Российской империи: Собр. 3-е. T. XXV: 1905. Санкт-Петербург, 1908. C. 237-238.

92 Состояние сектантства и раскола и деятельность православной миссии в Екатеринославской епархии в 1910 г. // EЕB. 1911. № 6. С. 165.
} 
пресвітерів. 3 часом штундисти почали святкувати й недільний день та усі Господні свята, хоча раніше заперечували, бо «про це не писалося в Євангелії». Почали учорашні штундисти вшановувати і страсну П’ятницю.

Представники офіційного баптизму заперечували факт блюзнірських практик у своїх громадах. Легалізований у 1905 р. баптизм волів виглядати поважно, намагаючись забути свій суперечливий штундистський досвід. Лідери баптизму переконували владу, що їхні віряни - просто зразково лояльні піддані, готові на все заради улюбленого імператора. На цьому наголошував один $з$ перших істориків штунди пастор Йоганн Пріцкау93. Новий статус зобов'язував баптистів і євангельських християн змінити не лише теологічні уявлення, але й спосіб життя і зовнішній вигляд. «Не можна не відзначити, - писав сучасник, - ще одну дуже характерну рису. На 43-й сторінці [журналу «Християнин» I.С. Проханова] розміщено фотографію учасників з'їзду у Петербурзі. На фото представлені особи, витончено зодягнені, навіть модно, виказуючи прагнення до гарного стилю. Мимоволі згадується недавнє минуле. Років десять тому багато хто з них босоніж мандрував селами, аргументуючи це тим, що “наш Христос так ходив і нас вчив" ${ }^{94}$. Про нівечення ікон у часи босоногої молодості баптисти згадувати не хотіли, хоч у повсякденні їхніх громад іконофобія спостерігалася тривалий час.

Чи була описана форма народної релігійності протестантизмом, інноваційною духовністю, релігійною модернізацією, радикальною Реформацією, втраченим шансом на європейський шлях культурного розвитку, як твердить низка авторів? Сподіваємося, наша стаття спонукатиме шукати альтернативні відповіді на ці питання.

\section{REFERENCES}

Ambartsumov, I. (2014). Nepravoslavnye khristianskie ispovedaniia $v$ sisteme rossiiskoi gosudarstvennosti (konets XIX veka- iiul 1914 g.) [Non-Orthodox Christian Confessions in the System of Russian Statehood (late 19th century - July 1914)]. (Candidate's thesis). Sankt-Peterburg [in Russian].

Aivazov, I. (1904). Sostoianie sektantstva i raskola i deiatelnost pravoslavnoi missii v Ekaterinoslavskoi eparkhii za $1903 \mathrm{~g}$. [The state of sectarianism and schism and the activities of the Orthodox mission in the Ekaterinoslav diocese in 1903]. Ekaterinoslavskie eparkhialnye vedomosti, 7, 216-221 [in Russian].

Apanasenok, A.V. (2010). Religioznye dissidenty $v$ rossiiskoi provintsii: ocherk istorii dukhovnykh dvizhenii Kurskoi gubernii v kontse XVIII - nachale XX veka [Religious dissidents in the Russian province: an outline of the history of the spiritual movements of the Kursk province in the late XVIIIth - early XXth centuries]. Kursk [in Russian].

Bakhtin, M. (1990). Tvorchestvo Fransua Rable i narodnaia kultura srednevekov'ia i Renessansa [Francois Rabelais' creativity and folk culture of the Middle Ages and Renaissance]. Moskva [in Russian].

Beznosova, 0. (2006). Evangelskoe dvizhenie v Rossiiskoi imperii (1850-1917): Ekaterinoslavskaia guberniia (Sbornik dokumentov i materialov) [Evangelical movement in the Russian Empire (18501917): Ekaterinoslavskaya province (Collection of documents and materials)]. Shtainkhagen: Samencorn [in Russian].

Belyi, M. (1904). Sektantstvo na khutore Uzeki Rostovskogo-na-Donu okruga [Sectarianism on the Uzeki farm of the Rostov-on-Don district]. Ekaterinoslavskie eparkhialnye vedomosti, 19, 625-630 [in Russian].

Bereznitskii, I. (1896). Dvadtsatiletniaia borba s prikhodskoiu shtundoiu i troekratnoe odolenie [Twenty Years' Struggle with the Parish Shtund and Threefold Defeat]. Missionerskoe obozrenie, iiul-

\footnotetext{
93 Прицкау И. История баптистов в южной России. Одесса, 1914. 190 с.

94 Замыслы сектантов. Журнал «Христианин». 1911. январь. № 1. Ред. И.С. Проханов // EЕВ. 1911. № 9. С. 264.
} 
avgust, 49-55 [in Russian].

Bogoliubov, D. (1902). Missionerskie besedy s sektantami [Missionary conversations with sectarians]. Kharkov [in Russian].

Bonch-Bruevich, V. (Ed.) (1908). Kratkoe zhizneopisanie baptista Egora Nikanorovicha Ivanova [Brief biography of the Baptist Yegor Nikanorovich Ivanov]. In Materialy $k$ istorii i izucheniiu russkogo sektantstva i raskola (Vol. 1, pp. 32-40). Sankt-Peterburg [in Russian].

Bulanova, N. (2007). Istoriia khrystyianskykh konfesii Katerynoslavshchyny ostannoi chverti XVIII pochatku XXst. [History of Christian denominations of Ekaterinoslav region of the last quarter of the XVIIIth - beginning of the XXth century]. Dnipropetrovsk [in Ukrainian].

Bulgakov, S. (1991). Pravoslavie. Ocherki ucheniia pravoslavnoi Tserkvi [Orthodoxy. Essays on the teachings of the Orthodox Church]. Kiev [in Russian].

Butkevich, T. (1914). Obzor russkikh sekt i ikh tolkov [Rewiew of the Russian sects and their branches]. Kharkov [in Russian].

Chernyshev, V.M. (2000). Mech oboiudoostryi. Konspekt po sektovedeniiu [A double-edged sword. Synopsis on sectology]. Kiev [in Russian].

Coleman, Heather J. (2005). Russian Baptists and Spiritual Revolution, 1905-1929. Bloomington [in English].

Dementiev, I. (1889). Iz dnevnika ekaterinoslavskogo eparkhialnogo missionera [From the diary of the Ekaterinoslav diocesan missionary]. Ekaterinoslavskie eparkhialnye vedomosti, 7, 179-192 [in Russian].

Dementiev, I. (1889). Iz dnevnika ekaterinoslavskogo eparkhialnogo missionera [From the diary of the Ekaterinoslav diocesan missionary]. Ekaterinoslavskie eparkhialnye vedomosti, 8, 205-219 [in Russian].

Dunaienko, F. (1995). Do kontsa preterpevshii [Endured to the end]. Retrieved from: http://www.rusbaptist.stunda.org/dunaenko.htm [in Russian].

Eliade, M. (1999). Traktat po istorii religii. Vol. 2 [Treatise on the History of Religions]. Sankt-Peterburg [in Russian].

Eliade, M. (2001). Mefistofel i androhin [Mephistopheles and androgyne]. Kyiv [in Ukrainian].

Eliade, M. (2010). Aspekty mifa [Aspects of myth]. Moskva [in Russian].

Gennep, A. van. (1999). Obriady perekhoda Sistematicheskoe izuchenie obriadov [Rites of passage. A systematic study of rituals]. Moskva [in Russian].

Ginzburg, K. (2000). Syr i chervi [Cheese and worms]. Moskva [in Russian].

Girts, K. (2004). Interpretatsiia kultur [Interpretation of cultures]. Moskva [in Russian].

Heretz, L. (2008) Russia on the eve Modernity. Popular religion and traditional culture under the last tsars. Cambridge Un. Press [in English].

Khytrovska, I.Yu. (2007). Pravoslavna tserkva ta shtundyzm na Pravoberezhnii Ukraini v druhii polovyni XIX - na pochatku XX st. [The Orthodox Church and Stundism in Right-Bank Ukraine in the Second Half of the XIXth and early of XXth centuries]. Intelihentsiia i vlada, 9, 73-84 [in Ukrainian].

Krasnokutskii, 0. (1889). 0 shaloputstve [About shaloputs]. Ekaterinoslavskie eparkhialnye vedomosti, 4, 85-92 [in Russian].

Kuznetsova Miriam R. (2009). Early Russian Evangelicals (1874-1929): Historical Background \& Hermeneutical Tendencies Based on I.V. Kargel's Written Heritage. Submitted in fulfilment of the requirements for the degree of for the degree of Doctor of Philosophy. University of Pretoria [in English].

Lebedintsev, P. (1885). Baptizm ili shtunda v Kievskoi gubernii [Baptism or shtunda in the Kiev province]. Kievskaia starina, 3, 491-518 [in Russian].

Levi-Briul, L. (1937). Sverkhieestestvennoe v pervobytnom myshlenii [The supernatural in primitive thinking]. Moskva [in Russian].

Lotman, I.M. (2002). Rol dualnykh modelei v dinamike russkoi kultury do kontsa XVIII v. In Istoriia i tipologiia russkoi kultury, (pp. 88-115). Sankt-Peterburg [in Russian].

Meletinskii, E. (2001). Ot mifa k literature [From myth to literature]. Moskva [in Russian].

Melnikova, E. (2006). Otchityvanie besnovatykh: praktiki i diskursy [Scolding the Possessed: Practices and Discourses]. Antropologicheskii forum, 4, 220-263 [in Russian].

Nazarevskii, N. (1911). O kreste i krestnom znamenii [About the cross and the sign of the cross]. Ekaterinoslavskie eparkhialnye vedomosti, 1, 26-27 [in Russian].

Nikolskaia, T. (2009). Russkii protestantizm i gosudarstvennaia vlast $v$ 1905-1991 gg. [Russian Protestantism and state power in 1905-1991]. Sankt-Peterburg [in Russian].

Opria, I. (2011). Utysky adeptiv piznoprotestantskykh konfesii u Pravoberezhnii Ukraini naprykintsi XIX 
- na pochatku XX st. [The prints of the adepts of the Protestant confessions near the Right Bank of Ukraine for example XIX - on the early of the XX century]. Ukrainskyi istorychnyi zhurnal, 2, 41-49 [in Ukrainian].

Otto, R. (2008). Sviashchennoe [Sacred]. Sankt-Peterburg [in Russian].

Piskliavskii, M. (1911). Zamysly sektantov Zhurnal «Khristianin». 1911, ianvar. Redaktor I. Prokhanov [The intentions of the sectarians. Christian magazine. 1911, January. Editor I. Prokhanov]. Ekaterinoslavskie eparkhialnye vedomosti, 9, 261-265 [in Russian].

Prysiazhniuk, I. (2007). Ukrainske selianstvo Naddniprianskoi Ukrainy: sotsiomentalna istoriia druhoi polovyny XIX - pochatku XX st. [Ukrainian settlement of Ukraine: social and historical history of the other half of the XIXth century - at the beginning of the XXth century]. Cherkasy [in Ukrainian].

Pritskau, I. (1914). Istoriia baptistov v Yuzhnoi Rossii [History of Baptists in Southern Russia]. Odessa [in Russian].

Romanova, O. (2010). Ochikuvannia «chuda» yak osnova narodnoi pobozhnosti (Kyivska mytropoliia, XVIII st.) [Expectation of a «miracle» as the basis of popular piety (Kyiv metropolitanate, XVIII century)]. Ukrainskyi istorychnyi zhurnal, 1, 84-106 [in Ukrainian].

Rozanov, V. (1995). Okolo tserkovnykh sten [Near the church walls]. Moskva [in Russian].

Savinskii, S.N. (1995). Istoriia russko-ukrainskogo baptizma [History of Russian-Ukrainian baptism]. Odessa [in Russian].

Skvortsov, V.M. (1898). Kurskoe ikonoborcheskoe zlodeianie i chudesnoe znamenie vo svidetelstvo istinnosti i sviatosti pravoslavnoi very [Kursk iconoclastic atrocity and a miraculous sign in witness to the truth and holiness of the Orthodox faith]. Missionerskoe obozrenie, aprel, 517-538 [in Russian].

Sharte, R. (2004). Intellektualnaia istoriia i istoriia mentalnostei: dvoinaia pereotsenka [Intellectual history and history of mentalities: a double reappraisal]. Novoe literaturnoe obozrenie. Paradigmy intellektualnoi istorii: ot kollektivnykh predstavlenii $k$ avtorskim intentsiiam. Retrieved from: https://magazines.gorky.media/nlo/2004/2 [in Russian].

Shalkinskii, S. (1908). Otchet o sostoianii raskola Ekaterinoslavskoi eparkhii v $1907 \mathrm{~g}$. [Report on the state of the split of the Yekaterinoslav diocese in 1907]. Ekaterinoslavskie eparkhialnye vedomosti, 8 , 163-169 [in Russian].

Smilianskaia, E. (2003). Volshebniki. Bogokhulniki. Eretiki. Narodnaia religioznost $i$ «dukhovnye prestupleniia» v Rossii XVIII v. [Wizards. Blasphemers. Heretics. Folk religiosity and «spiritual crimes» in Russia of the XVIIIth century]. Moskva [in Russian].

Stepniak-Kravchinskii, S. (1997) Shtundist Pavel Rudenko [Shtundist Pavel Rudenko]. Retrieved from: http://www.rusbaptist.stunda.org/shtundist.htm [in Russian].

Timoshenko, M. (1911). Baptisty i ikh protivniki [Baptists and their opponents]. Baptist, 9, 66-69 [in Russian].

Troitskii, S. (1905). V kakom otnoshenii uchenie russkogo shtundizma nakhoditsia k nemetskomu protestantizmu [In what relation is the teaching of Russian Stundism related to German Protestantism]. Missionerskoe obozrenie, 1, 55-77 [in Russian].

Uspenskii, B. (1982). Filologicheskie razyskaniia $v$ oblasti slavianskikh drevnostei [Philological research in the field of Slavic antiquities]. Moskva [in Russian].

Zhuk, S. (2004). Russia's Lost Reformation. Peasants, Millennialism, and Radical Sects in Southern Russia and Ukraine, 1830-1917. Washington [in English].

\section{Serhii Savchenko}

(National Metallurgical Academy of Ukraine, Dnipro, Ukraine)

e-mail: serhijs@gmail.com

ORCID: https://orcid.org/0000-0002-3615-2343

\section{Sacrilege as 'True Piety': Religious Practices of Stundists Peasants in the Second Half of the $19^{\text {th }}-$ Early $20^{\text {th }}$ Century}

The role and place of sacrilege practices regarding icons and other Orthodox sacraments in the religious life of Stundists communities of Ukraine in the late $19^{\text {th }}$ - early $20^{\text {th }}$ century are studied. A number of historiographical stereotypes about the history of sectarian movements of the late imperial period are refuted. The thesis is substantiated that those practices were decisive for the formation of the confessional identity of Stundists peasants. 
Committing sacrilege over the icons and other Orthodox sacred objects for Stundists was a means of initiation into the community of the chosen, a tool of provocation to cause persecution to recall the history of early Christianity, a consequence of inversion thinking and a product of archaic mentality. There is no reason to identify all Stundists of the $60 \mathrm{~s}-80 \mathrm{~s}$ of the $19^{\text {th }}$ century with Protestantism.

Despite the undoubted influence of German colonists and preachers on the emergence of Ukrainian peasant Stunda, Stundists in their sacrilege actions were almost not guided by usual Protestant arguments. As a rule, they did not identify themselves with Protestantism and its theological doctrines. At early $20^{\text {th }}$ century after introducing religious tolerance in the legal field of the Empire, the use of sacred images became the norm in legitimate Baptists communities, but was still rejected by rural Baptists.

Keywords: Stundists, Stunda, icons, iconoclasm, missionaries, church 